\title{
Dietary L-Carnitine Supplement Counteracts Pulmonary Hypertensive Response in Broiler Chickens Fed Reduced-Protein Diets and Subjected to Cool Condition and Hypobaric Hypoxia
}

\author{
Mohammad R. Sharifi ${ }^{1}$, Hossein Hassanpour ${ }^{2}$ and Fariborz Khajali ${ }^{1}$ \\ ${ }^{1}$ Department of Animal Science, Shahrekord University, Shahrekord, 88186-34141, Iran \\ ${ }^{2}$ Department of Basic Science, Shahrekord University, Shahrekord, 88186-34141, Iran
}

\begin{abstract}
The present study was carried out to evaluate the effects of supplementing reduced-protein diets with L-carnitine on growth performance and occurrence of pulmonary arterial hypertension (PAH) syndrome in broiler chickens reared at high altitude. A total of 156 day-old male broilers (Ross 308) were assigned to three dietary treatments and reared up to 42 days of age. A normal-protein diet (NPD) was formulated according to the National Research Council (1994) and served as control. A reduced-protein diet (RPD) was also prepared to contain 3\% less protein than that of the NPD. An additional RPD diet was prepared by supplementing L-carnitine (LC) at $100 \mathrm{mg} / \mathrm{kg}$ to the RPD. Results showed significant improvements in feed:gain and carcass yield in birds fed on RPD when supplemented with LC. The proportions of liver, heart, and abdominal fat pad relative to body weight and the right ventricular weight ratio (RV:TV) were significantly higher in birds fed on the RDP than those of the control fed the NPD. Electrocardiogram (ECG) measurements recorded from lead II supported the development of PAH in birds fed RPD as evidenced by deep $\mathrm{S}$ waves. Supplementing LC to the RPD significantly reduced the liver weight, abdominal fat deposition, and RV:TV, which reflected in reduced $\mathrm{S}$ waves. Feeding broilers with the RPD significantly reduced serum concentrations of nitric oxide (NO) and uric acid (UA). However, supplementation of the RPD with LC significantly increased the serum concentrations of NO. In conclusion, feeding reduced-protein diets to broilers reared at hypobaric hypoxia increases their susceptibility to pulmonary hypertension. Dietary LC supplementation of reduced-protein diets had beneficial effects in preventing PAH mortality mainly through enhancing blood NO concentration.
\end{abstract}

Key words: broiler ascites, carnitine, lipogenesis, nitic oxide

J. Poult. Sci., 52: 206-212, 2015

\section{Introduction}

L-carnitine (LC) is the main component of carriermediated enzymatic shuttle in the inner membrane of mitochondria, which transport long-chain fatty acids from the cytoplasm to the mitochondrial matrix. The carnitine palmitoyltransferase is the enzyme responsible for this shuttle mechanism. Long-chain fatty acids entered the mitochondrial matrix are subjected to $\beta$-oxidation process, which is the main lipolytic pathway. Xu et al. (2003) investigated the effect of dietary LC supplement ( 0 to $100 \mathrm{mg} / \mathrm{kg}$ ) on growth performance and fat metabolism in broilers. They observed a decrease in abdominal fat and muscle fat contents when LC was supplemented to diets at greater than $25 \mathrm{mg} / \mathrm{kg}$. Lien

Received: December 29, 2014, Accepted: February 26, 2015

Released Online Advance Publication: April 25, 2015

Correspondence: Dr. F. Khajali, Department of Animal Science, Shahrekord

University, Shahrekord, Postcode: 88186-34141, Iran.

(E-mail: khajali@agr.sku.ac.ir) and Horng (2001) indicated that carnitine palmitoyl transferase activity in the carnitine-supplemented group was significantly $(P<0.05)$ higher in birds received dietary LC supplement compared to the control. However, LC supplement had no effect on the activities of fatty acid $\beta$-oxidation enzymes. Rodehutscord et al. (2002) reported that LC supplement $(80 \mathrm{mg} / \mathrm{kg})$ did not significantly improve the efficiencies of energy and protein utilization, suggesting LC may have other important biological impacts. Yousefi et al. (2013) indicated that LC supplement $(100 \mathrm{mg} / \mathrm{kg})$ increased circulatory level of nitric oxide (NO), an important cellular signaling molecule involved in many physiological processes. Nitric oxide is also a powerful vasodilator that prevents pulmonary hypertension (Izadinia et al., 2010; Khajali et al., 2011a). Besides, LC has been shown to play an antioxidant role in animal metabolism (Lee et al., 2014).

Research has shown that mortality from pulmonary arterial hypertension (PAH) syndrome was significantly increased in broiler chickens fed on reduced-protein diets and reared at 
high altitude (Behrooj et al., 2012). Intensive lipogenesis and reduced concentrations of nitric oxide and uric acid have been suggested to account for increased mortality from PAH (Behrooj et al., 2012). These mechanisms have been reviewed in details by Khajali and Wideman (2015). Feeding reduced-protein diets to poultry is an environmentally friendly practice to prevent environmental pollution with nitrogen (Khajali et al., 2008). However, this nutritional approach may need to be reconsidered when exercised for broilers grown at high altitude. The objective of the present study was to evaluate effects of LC on the occurrence of $\mathrm{PAH}$ in broiler chickens fed reduced-protein diets and reared at high altitude.

\section{Material and Method}

\section{Birds and Experimental Facility}

The experiment was carried out in an area with an altitude of 2,100 $\mathrm{m}$ above sea level. The experimental animals were kept, maintained and treated in strict accordance with the recommendations in the Guide for the Care and Use Committee of Shahrekord University.

A total of 156 day-old male broilers (Ross 308) were randomized across 12 floor pens. Each pen measured $1.8 \mathrm{~m}^{2}$ (13 birds per pen) and was equipped with a bell drinker and a feed trough. All chicks were raised on a commercial starter diet until five days of age. Following a $6 \mathrm{~h}$ fast, chicks were allocated to litter pens so that all pens had equal initial body weights $(1157 \mathrm{~g} \pm 10 \mathrm{~g})$. The shed temperature was set at 32 $\pm 1^{\circ} \mathrm{C}$ at placement and reduced to $25 \pm 1^{\circ} \mathrm{C}$ at $7 \mathrm{~d}, 20 \pm 1^{\circ} \mathrm{C}$ at $14 \mathrm{~d}$ and $15 \pm 1^{\circ} \mathrm{C}$ at $21 \mathrm{~d}$ onward (until the end of trial at 42 days of age)(Saffar and Khajali, 2010; Khajali et al., 2014). Birds were subjected to $23 \mathrm{hr}$ light and $1 \mathrm{hr}$ dark throughout the trial and they had free access to feed and water.

Dietary treatments were formulated according to the NRC (1994) recommendations. A commercial broiler diet with normal-protein content was prepared and served as control (designated as NPD). The NPD met or exceeded the requirements for all essential amino acids. A reduced-protein diet (designated as RPD) was also prepared containing $30 \mathrm{~g}$ less crude protein per $\mathrm{kg}$ of diet relative to NPD. Another dietary treatment was prepared by supplementing $100 \mathrm{mg} / \mathrm{kg}$ L-carnitine (Carniking ${ }^{\circledR}$, Lohmann Animal Health, Cuxhaven, Germany) to RPD. All diets had the same level of metabolizable energy and offered in mash feed. Potassium carbonate was also added to the reduced-protein diets to equalize the dietary electrolyte balance $(\mathrm{Na}+\mathrm{K}-\mathrm{Cl})$ of all dietary treatments. The compositions of the experimental diets are shown in Tables 1.

Prior to starting the experiment, samples of feed ingredients as well as mixed diets were analyzed for crude protein and amino acid contents. Crude protein content of experimental diets was determined according to AOAC (2000). For the determination of amino acid content, duplicate samples of each ingredient or diet were subjected to $6 \mathrm{~N} \mathrm{HCl}$ and hydrolyzed for $24 \mathrm{~h}$ at $110^{\circ} \mathrm{C}$ (Andrew and Baldar, 1985). After acid hydrolysis, all samples were analyzed for amino acid content by using an ion-exchange chromatograph (LKB Biochrom 4141; Cambridge, UK). Performic acid oxidation was done to determine sulfur amino acids as well (Moore and Stain, 1963).

\section{Measurements}

Records of feed intake and weight gain were obtained for entire trial ( 5 to 42 days of age). Feed:gain data was also calculated and corrected for mortality body weights in entire trial. At 42 days of age, 8 birds per treatment were selected for blood collection. Blood samples $(3 \mathrm{~mL})$ were collected from the brachial vein and centrifuged at $2,500 \times \mathrm{g}$ for $10 \mathrm{~min}$ to obtain sera. Serum samples were used for the determination of nitric oxide (NO), uric acid (UA) and malondialdehyde (MDA). Serum NO (nitrate+ nitrite) was measured according to Behrooj et al. (2012). This assay was based on the reduction of nitrate to nitrite by cadmium. Serum samples were deproteinised by adding $75 \mathrm{mmol} \mathrm{ZnSO}_{4}$ and 55 $\mathrm{mmol} \mathrm{NaOH}$. Samples were then centrifuged and the resulting supernatants were diluted with glycine buffer $(45 \mathrm{~g} / \mathrm{L}$; $\mathrm{pH}$ 9.7). Freshly activated cadmium granules $(\sim 2 \mathrm{~g}$ rinsed three times in deionized water and swirled in $5 \mathrm{mmol} \mathrm{CuSO}_{4}$ in glycine-NaOH buffer $5 \mathrm{~g} / \mathrm{L}$; $\mathrm{pH}$ 9.7) were added to samples. Upon continuous stirring for $10 \mathrm{~min}$, the samples were transferred to new tubes and subjected to Griess reaction. Griess reagent 1 ( $1 \%$ sulfanilamide in $5 \%$ phosphoric acid) was added to the sample tubes and incubated for $10 \mathrm{~min}$ at room temperature while protected from light. Griess reagent 2 (N-napthylethylenediamine dihydrochloride in water) was then dispensed to all samples and the absorbance of $\mathrm{NO}_{2}{ }^{-}$ was measured at $540 \mathrm{~nm}$ within $10 \mathrm{~min}$ by a spectrophotometer (Corning 480, Corninig, New York, NY, USA).

Serum UA concentration was analyzed colorometrically according to Fossati et al. (1980) using 3,5-dichloro-2-hydroxybenzene sulfonic acid/4-aminophenazone chromogenic system in the presence of horseradish peroxidase and uricase. The red color formation was then measured at $520 \mathrm{~nm}$. MDA concentration in the serum samples was measured as an index of lipid peroxidation by the TBARS (thiobarbituric acid reactive substances) method (Nair and Turner, 1984). MDA is formed as a result of lipid peroxidation and reacts with thiobarbituric acid under high temperature $\left(90-100^{\circ} \mathrm{C}\right)$ and acidic condition. The reaction yields a pink MDA-TBA adduct. The colored complex was measured by a spectrophotometer at $535 \mathrm{~nm}$.

Samples of blood were also collected in microhematocrit tubes for measuring hematocrit. An aliquot of blood was also obtained on glass slides to prepare the blood smear for the determination of differential leukocyte count. May Grunwald-Giemsa staining was used $3 \mathrm{~h}$ after methyl alcohol fixation (Lucas and Jamroz, 1961). One hundred leukocytes including granular (heterophils) and nongranular (lymphocytes) were enumerated and the heterophil to lymphocyte ratio $(\mathrm{H}: \mathrm{L})$ was calculated. All chemical reagents were obtained from Sigma-Aldrich Co. (Sigma-Aldrich Co., St. Louis, MO, USA).

At the end of trial (day 42), 8 additional birds per treatment were euthanized for carcass processing. Data obtained 
Table 1. Compositions of normal- and reduced-protein diets fed to broilers in the starter/grower and finisher periods

\begin{tabular}{lcccc}
\hline \hline & \multicolumn{2}{c}{ Starter/grower $(5-21 \mathrm{~d})$} & \multicolumn{2}{c}{ Finisher (21-42d) } \\
Ingredient (g/kg unless noted) & $\begin{array}{c}\text { Normal- } \\
\text { protein }\end{array}$ & $\begin{array}{c}\text { Reduced- } \\
\text { protein }\end{array}$ & $\begin{array}{c}\text { Normal- } \\
\text { protein }\end{array}$ & $\begin{array}{c}\text { Reduced- } \\
\text { protein }\end{array}$ \\
\hline Yellow corn & 469 & 548 & 562 & 660 \\
Soybean meal & 392 & 335 & 330 & 244 \\
Fish meal & 25 & 10 & 10 & 5 \\
Soya oil & 75 & 65 & 61 & 47 \\
Dicalcium phosphate & 15 & 17 & 13 & 14 \\
Oyster shell & 14 & 14.5 & 15 & 15.5 \\
Sodium chloride & 3.5 & 3.5 & 3 & 3 \\
DL- methionine & 1 & 2 & 1 & 2 \\
L-Lysine HCl & - & - & - & 2 \\
Vitamin premix & 2.5 & 2.5 & 2.5 & 2.5 \\
Trace mineral premix & & 2.5 & 2.5 & 2.5 \\
Potassium carbonate & 2.5 & 2 & - & 2.5 \\
Analyzed crude protein & - & 199 & 198 & 169 \\
Analyzed Met + Cys & 227 & 8.7 & 7.3 & 7.3 \\
Analyzed Lys & 8.9 & 11.0 & 10.7 & 10.1 \\
Analyzed Arg & 13.1 & 8.4 & 12.6 & 11.0 \\
Analyzed Thr & 15 & 13.38 & 13.38 & 7.5 \\
Calculated metabolizable energy & 13.38 & & & 13.38 \\
(MJ/kg) & & 236 & 222 & 222 \\
Calculated Na + K-Cl (meq/kg) & 235 & & & \\
\hline
\end{tabular}

${ }^{1}$ Provided the following per kg of diet: vitamin A (trans-retinylvacetate), $1.08 \mathrm{mg}$; vitamin $\mathrm{D}_{3}$ (cholecalciferol), $0.02 \mathrm{mg}$; vitamin $\mathrm{E}$ (dl-tocopheryl acetate), $7.2 \mathrm{mg}$; vitamin $\mathrm{K}_{3}, 1.6 \mathrm{mg}$; vitamin $B_{1}, 0.72 \mathrm{mg}$; vitamin $B_{2}, 3.3 \mathrm{mg}$; vitamin $B_{3}, 0.4 \mathrm{mg}$; vitamin $B_{6}, 1.2 \mathrm{mg}$; vitamin $B_{12}, 0.6$ $\mathrm{mg}$; folic acid, $0.5 \mathrm{mg}$; choline chloride, $200 \mathrm{mg}$.

${ }^{2}$ Provided the following per $\mathrm{kg}$ of diet: $\mathrm{Mn}$ (from $\mathrm{MnSO}_{4} \cdot \mathrm{H}_{2} \mathrm{O}$ ), $40 \mathrm{mg}$; $\mathrm{Zn}$ (from $\mathrm{ZnO}$ ), $40 \mathrm{mg}$; $\mathrm{Fe}$ (from $\mathrm{FeSO}_{4} \cdot 7 \mathrm{H}_{2} \mathrm{O}$ ), $20 \mathrm{mg}$; $\mathrm{Cu}$ (from $\mathrm{CuSO}_{4} \cdot 5 \mathrm{H}_{2} \mathrm{O}$ ), $4 \mathrm{mg}$; I (from $\mathrm{Ca}\left(\mathrm{IO}_{3}\right)_{2} \cdot \mathrm{H}_{2} \mathrm{O}$ ), 0.64 $\mathrm{mg}$; Se (from sodium selenite), $0.08 \mathrm{mg}$.

L-carnitine was added at the top of reduced-protein diet at $100 \mathrm{mg} / \mathrm{kg}$.

at processing included hot eviscerated carcass weight, breast weight, liver weight and abdominal fat deposition. The hearts were also harvested and the ventricles were dissected and weighed to calculate the right-to-total ventricular weight ratio (RV:TV ratio). Mortality from PAH was checked daily and identified by RV:TV values greater than 0.299 (Walton et al., 2001).

\section{Electrocardiographic Recording}

Neither sedative nor anesthetic material was used for the ECG recordings. The chickens were placed in a ventral (sternal upright) recumbent position on a plastic-covered table. In easily stressed birds, the head was covered with a surgical cloth to relieve stress during handling. Four alligator clip electrodes were connected to the cranial area of the skin fold in the angle between the arm and forearm of the left and right wings (propatagium) and to the skin on the left and right skin over the cranial cnemial crest. The use of alligator clips without sharp teeth avoided any damage to the feathers and skin. All procedures took place in an isolated room to minimize the stress to the birds. Eight chicks per treatment were randomly selected at day 40 and electrocardiograms (ECG) were recorded. The electrocardiograph (Kenz ECG 110, SUZUKEN CO., LTD. Nagoya, Japan) was standardized at $10 \mathrm{~mm}=1 \mathrm{mV}$ with a chart speed of $50 \mathrm{~mm} / \mathrm{s}$ (Hassanpour et al., 2009; Yousefi et al., 2013). Leads II was recorded for every chicken, and the amplitude of the T, R and $\mathrm{S}$ waves were measured.

\section{Statistical Analysis}

Results were analyzed by GLM procedure of SAS (2007) software in a completely randomized design. For live performance data, the individual experimental unit was the pen of birds and a completely randomized analysis of variance was used to compare the treatment means in a model as $Y_{\mathrm{ij}}=$ $\mu+\mathrm{T}_{\mathrm{i}}+\mathrm{e}_{\mathrm{ij}}$. For blood (haematocrit, H:L), sera (NO, UA, and MDA) and carcass (carcass yield, breast yield, liver and heart percentages, abdominal fat deposition and RV:TV) data, where there was sampling within pens, data were subjected to a nested design and the model was $Y_{\mathrm{ijk}}=\mu+T_{i}$ + eij $+\varepsilon_{i j k}$. In these models, $Y_{i j}$ and $Y_{i j k}$ are observations; $\mu$ is the general location parameter (i.e., the mean); $T_{i}$ is the effect for being in treatment $\mathrm{i}$; $\mathrm{e}_{\mathrm{ij}}$ is random error; and $\varepsilon_{\mathrm{ijk}}$ is subsampling error. The probability level of $P<0.05$ was chosen to present significant differences for all data. Means were separated by the Duncan's multiple range test. 
Table 2. Effect of L-carnitine supplementation of reduced-protein diets on cardiac/electrocardiographic (lead II) wave amplitudes and PAH mortality

\begin{tabular}{lcccc}
\hline \hline \multicolumn{1}{c}{ Variables } & NPD & RPD & $\begin{array}{c}\text { RPD }+ \\
\text { L-carnitine }\end{array}$ & P-value \\
\hline R wave $(\mathrm{mV})$ & $0.21 \pm 0.035$ & $0.22 \pm 0.035$ & $0.23 \pm 0.026$ & 0.8974 \\
S wave $(\mathrm{mV})$ & $-0.30^{\mathrm{b}} \pm 0.016$ & $-0.38^{\mathrm{a}} \pm 0.019$ & $-0.31^{\mathrm{b}} \pm 0.030$ & 0.0308 \\
T wave $(\mathrm{mV})$ & $0.15 \pm 0.018$ & $0.18 \pm 0.035$ & $0.15 \pm 0.017$ & 0.6940 \\
PAH mortality (\%) & $20.1^{\mathrm{ab}} \pm 4.24$ & $28.3^{\mathrm{a}} \pm 3.33$ & $17.5^{\mathrm{b}} \pm 0.39$ & 0.0460 \\
RV:TV in PAH birds & $0.39 \pm 0.023$ & $0.41 \pm 0.019$ & $0.39 \pm 0.018$ & 0.2015 \\
\hline
\end{tabular}

Each mean represents values from 8 replicates.

NPD: normal-protein diet; RPD: reduced-protein diet; L-carnitine: used at $100 \mathrm{mg} / \mathrm{kg}$

PAH: pulmonary arterial hypertension; RV:TV: right to total ventricular weight ratio

Table 3. Effect of L-carnitine supplementation of reduced-protein diets on carcass characteristics in broiler chickens measured at 42 days of age

\begin{tabular}{lcccc}
\hline \multicolumn{1}{c}{ Variables } & NPD & RPD & $\begin{array}{c}\text { RPD }+ \\
\text { L-carnitine }\end{array}$ & P-value \\
\hline Carcass yield (g/kg) & $675^{\mathrm{a}} \pm 4.26$ & $645^{\mathrm{b}} \pm 12.19$ & $679^{\mathrm{a}} \pm 11.50$ & 0.0467 \\
Breast yield (g/kg) & $363 \pm 7.17$ & $356 \pm 7.61$ & $363 \pm 13.98$ & 0.7862 \\
Liver (live body weight (\%)) & $2.38^{\mathrm{b}} \pm 0.06$ & $2.87^{\mathrm{a}} \pm 0.19$ & $2.21^{\mathrm{b}} \pm 0.11$ & 0.0108 \\
Heart (\%) & $0.58^{\mathrm{b}} \pm 0.18$ & $0.72^{\mathrm{a}} \pm 0.041$ & $0.65^{\mathrm{ab}} \pm 0.023$ & 0.0333 \\
Abdominal fat (\%) & $1.07^{\mathrm{b}} \pm 0.076$ & $1.41^{\mathrm{a}} \pm 0.078$ & $1.14^{\mathrm{b}} \pm 0.115$ & 0.0252 \\
RV:TV & $0.24^{\mathrm{b}} \pm 0.010$ & $0.30^{\mathrm{a}} \pm 0.023$ & $0.23^{\mathrm{b}} \pm 0.014$ & 0.0178 \\
\hline
\end{tabular}

Each mean represents values from 8 replicates.

NPD: normal-protein diet; RPD: reduced-protein diet; L-carnitine: used at $100 \mathrm{mg} / \mathrm{kg}$

$\mathrm{RV}: \mathrm{TV}$ right to total ventricular weight ratio

\section{Results}

There was a significant $(P=0.0308)$ negative increase in $\mathrm{S}$ wave amplitude of birds fed RPD compared with NPD (Table 2). L-carnitine supplement restored the situation so that it had no significant difference with NPD. There were no significant differences for $\mathrm{R}$ and $\mathrm{T}$ wave amplitudes among the treatments. Cumulative PAH mortality was significantly reduced by LC supplementation (Table 2).

Table 3 depicts carcass variables measured at the end of experiment (42 days). Feeding RPD was associated with a significant $(P=0.0467)$ reduction in carcass yield when compared to NPD. Supplementing RPD with LC restored the situation so that no difference was observed for carcass yield in comparison with NPD. The proportional weights of liver $(P=0.0108)$, heart $(P=0.0333)$, abdominal fat $(P=$ $0.0252)$ and the RV:TV $(P=0.0178)$ ratio were significantly higher in birds fed on RPD compared to those fed on NPD. Supplementing LC to RPD restored the situation.

Effects of dietary treatments on serum and blood variables are presented in Table 4. Circulatory level of NO in birds fed RPD was significantly $(P=0.0013)$ lower than birds fed NPD. The level of NO, however, significantly $(P=0.0013)$ increased by supplementation of RPD with LC though it was still lower than NPD. Serum uric acid concentration significantly reduced $(P=0.0057)$ in birds fed RPD with or without
LC supplement when compared to NPD. Though hematocrit did not influence by dietary protein content and LC supplementation, the $\mathrm{H}: \mathrm{L}$ ratio was significantly $(P=0.0034)$ increased in birds fed RPD when compared to those fed on NPD. Supplementing RPD with LC reduced the H:L ratio to the same level observed in NPD. No significant difference was observed among dietary treatments in terms of MDA.

Body weight gain, feed intake and feed:gain throughout the trial were not significantly different between NPD and RPD. However, LC supplementation of RPD significantly $(P=0.05)$ improved feed:gain (Table 5).

\section{Discussion}

There was no significant change in growth performance of broilers as a result of reduction in dietary protein content. This finding is in agreement with previous research (Laudadio et al., 2012). Supposedly, if reduced-protein diets are adequately supplemented with essential amino acids to meet the nutritional requirements of birds, growth performance can be comparable to those fed conventional (normalprotein) diets. Supplemental LC had no significant effect on body weight gain and feed intake but significantly improved feed:gain, which is in line with previous reports (Rabie and Szilagyi, 1998). Moreover, carcass yield significantly increased by LC supplementation of RDP. Though studies on broilers reared at normoxic condition and fed normal-protein 
Table 4. Effect of L-carnitine supplementation of reduced-protein diets on blood and serum variables in broiler chickens

\begin{tabular}{lcccc}
\hline \hline \multicolumn{1}{c}{ Variables } & NPD & RPD & $\begin{array}{c}\text { RPD }+ \\
\text { L-carnitine }\end{array}$ & P-value \\
\hline Serum nitric oxide $(\mu \mathrm{mol})$ & $15.60^{\mathrm{a}} \pm 0.73$ & $9.91^{\mathrm{c}} \pm 1.31$ & $12.64^{\mathrm{b}} \pm 0.90$ & 0.0013 \\
Serum uric acid $(\mathrm{mM} / \mathrm{L})$ & $0.37^{\mathrm{a}} \pm 0.026$ & $0.27^{\mathrm{b}} \pm 0.015$ & $0.30^{\mathrm{b}} \pm 0.17$ & 0.0057 \\
Serum malondialdehyde $(\mu \mathrm{mol})$ & $2.44 \pm 0.44$ & $3.87 \pm 0.51$ & $2.41 \pm 0.48$ & 0.1114 \\
Hematocrit $(\%)$ & $40.6 \pm 1.16$ & $43.8 \pm 2.65$ & $40.0 \pm 1.07$ & 0.4310 \\
H:L & $0.61^{\mathrm{b}} \pm 0.030$ & $0.86^{\mathrm{a}} \pm 0.075$ & $0.60^{\mathrm{b}} \pm 0.074$ & 0.0034 \\
\hline
\end{tabular}

Each mean represents values from 8 replicates.

NPD: normal-protein diet; RPD: reduced-protein diet; L-carnitine: used at $100 \mathrm{mg} / \mathrm{kg}$

H:L: heterophils to Lymphocytes

Table 5. Effect of L-carnitine supplementation of reduced-protein diets on performance of broiler chickens

\begin{tabular}{lllll}
\hline \multicolumn{1}{c}{ Variables } & NPD & RPD & $\begin{array}{c}\text { RPD }+ \\
\text { L-carnitine }\end{array}$ & P-value \\
\hline Total weight gain $(\mathrm{g} / \mathrm{b})$ & $2351 \pm 54.7$ & $2235 \pm 38.5$ & $2252 \pm 69.4$ & 0.3282 \\
Total feed intake $(\mathrm{g} / \mathrm{b})$ & $4414 \pm 94.9$ & $4242 \pm 71.1$ & $4150 \pm 104.0$ & 0.1705 \\
Feed:gain & $1.87^{\mathrm{ab}} \pm 0.012$ & $1.90^{\mathrm{a}} \pm 0.014$ & $1.84^{\mathrm{b}} \pm 0.013$ & 0.0500 \\
\hline
\end{tabular}

Each mean represents values from 4 replicates.

NPD: normal-protein diet; RPD: reduced-protein diet; L-carnitine was added at the top of RPD at 100 $\mathrm{mg} / \mathrm{kg}$.

diets indicated that LC did not influence feed efficiency and carcass yield of broiler chickens (Buyse et al., 2001; Lien and Horng, 2001), this dietary supplement improves feed efficiency and carcass yield for broilers subjected to hypoxic condition and fed on reduced-protein diets.

Feeding the RPD caused a significant increase in relative weight of liver and abdominal fat deposition when compared to the NPD. This finding demonstrates intensive hepatic lipogenesis occurred by feeding reduced-protein diets. In line with our observations, Rosebrough et al. (1999) showed that feeding reduced-protein diets intensified liver lipogenesis. In birds, the liver is the principal site of lipogenesis whereas adipose tissues account for a very limited lipogenesis (Stevens, 1996). Intensive lipogenesis can be reflected in increased abdominal fat deposition (Hood, 1984; Rosebrough et al., 1999).

Feeding reduced- protein diet significantly increased the relative weight of heart and the RV:TV ratio. The RV:TV ratio is indicative of PAH (Saedi and Khajali, 2010; Wideman et al., 2011; Ahmadipour et al., 2015). It is evident that chickens fed on RPD were expressing complications associated with PAH. In fact, intensive lipogenesis incurs high oxygen demand and push the right ventricle to pump more blood to the lungs for oxygenation. Subsequent overwork of heart especially the right ventricle causes right ventricular hypertrophy, which is manifested as increased RV:TV. Interestingly, LC supplement significantly reduced RV:TV in birds fed on RPD by suppressing lipogenesis and increasing circulatory level of NO. Nitric oxide is a potent vasodilator that opposes the onset of PAH in broiler chickens (Khajali and Wideman, 2010; Khajali et al., 2011b). In agreement with our study, Tan et al. (2008) reported a lower RV:TV in broilers fed with LC. Several mechanisms have been explained the role of LC in increased production of NO. Erbas et al. (2007) indicated that LC increased NO through the reduction in the activity of arginase and elevation in the activity of NO synthase. Another study by Sharifi et al. (2009) showed that LC could reduce the activity of angiotensin converting enzyme, which resulted in higher NO production. Recent research revealed that LC could increase NO production through activation of phosphatidylinositol 3kinase and subsequent stimulation of endothelial nitric oxide synthase (eNOS) (Ning and Zhao, 2013). In line with our finding, Yousefi et al. (2013) indicated that LC supplement $(100 \mathrm{mg} / \mathrm{kg})$ increased circulatory level of NO. The changes observed herein have been reflected in ECG of birds in this study. Electrocardiogram indicates that the amplitude of the $\mathrm{S}$ waves is significantly reduced by administration of Lcarnitine to the broilers fed on RDP. Kirby et al. (1999) reported a relatively high correlation between $\mathrm{S}$ wave amplitude and RV:TV. Negatively lower $\mathrm{S}$ wave amplitudes in broilers received L-carnitine suggest a lower rate of right ventricular hypertrophy and dilation. Altogether, these observations explain a significant reduced in mortality from PAH observed in birds fed LC-supplemented RPD. Olkowski et al. (2007) reported that the LC content of heart in broilers with heart failure was lower than in healthy broilers. They reported that lower level of myocardial LC 
was attributed to deterioration of heart function (Olkowski et al., 2007).

Plasma UA was significantly reduced in the chickens fed RPD compared to those fed NPD. Blood UA contributes to the protection of tissues against reactive oxygen species (ROS) (Machin et al., 2004). Reduced production of UA in birds fed on reduced-protein diets was reported to contribute to the development of PAH (Behrooj et al., 2012). No significant effect on uric acid was noted due to adding LC to RDP group. Hematocrit and MDA level were not significantly changed by feeding reduced-CP diets and LC supplementation. Heterophils to lymphocytes ratio (H:L) was significantly increased by feeding RPD. The H:L ratio is an index of stress in the chicken (Khajali et al., 2011a) and its higher value suggests birds fed on RPD are under stress presumably because they are suffering from pulmonary hypertension. Supplementing LC to RPD significantly reduced the $\mathrm{H}: \mathrm{L}$ ratio and this suggests therapeutic effects of $\mathrm{LC}$ in amelioration of PAH.

\section{Conclusion}

In general, feeding reduced-protein diets to broilers reared at hypobaric hypoxia increases their susceptibility to pulmonary arterial hypertension and causes PAH mortality. Dietary L-carnitine supplementation of reduced-protein diets has beneficial effects in counteracting the problem mainly by enhancing blood NO concentration.

\section{References}

Ahmadipour B, Hassanpour H, Asadi E, Khajali F, Rafiei F and Khajali F. Kelussia odoratissima Mozzaf- A promising medicinal herb to prevent pulmonary hypertension in broiler chickens reared at high altitude. Journal of Ethnopharmacology, 159: 49-54. 2015.

Andrew RP and Baldar NA. Amino acid analysis of feed constituents. Science Tools, 32: 44-48. 1985.

AOAC. Official Methods of Analysis 17th ed. AOAC International. Gaithersburg, MD. USA. 2000.

Behrooj N, Khajali F and Hassanpour H. Feeding reduced protein diets to broilers subjected to hypobaric hypoxia is associated with development of pulmonary hypertension syndrome. British Poultry Science, 53: 658-664. 2012.

Buyse J, Janssens GP and Decuypere E. The effects of dietary Lcarnitine supplementation on the performance, organ weights and circulating hormone and metabolite concentrations of broiler chickens reared under a normal or low temperature schedule. British Poultry Science, 42: 230-241. 2001.

Erbas H, Aydogdu N, Usta U and Erten O. Protective role of carnitine in breast cancer via decreasing arginase activity and increasing nitric oxide. Cell Biology International, 31: 14141419. 2007.

Fossati PP, Rincipe L and Berti G. Use of 3, 5-dichloro-2-hydroxybenzene sulfonic acid/4-aminophenazone chro-mogenic system in the direct enzymic assay of uric acid in serum and urine. Clinical Chemistry, 26: 227-231. 1980.

Hassanpour H, Zamani-Moghaddam AK and Zarei H. Effect of citric acid on electrocardiographic parameters of broiler chickens with pulmonary hypertension. Acta Veterinaria Hungarica, 57: 229-238. 2009 .
Hood RL. Cellular and biochemical aspects of fat deposition in the broiler chicken. World's Poultry Science Journal, 38: 194-200. 1984.

Izadinia M, Nobakht M, Khajali F, Faraji M,Zamani F, Qujeq D and Karimi I. Pulmonary hypertension and ascites as affected by dietary protein source in broiler chickens reared in cool temperature at high altitudes. Animal Feed Science and Technology, 155: 194-200. 2010.

Khajali F and Wideman RF. Dietary arginine: Metabolic, environmental, immunological and physiological interrelationships. World's Poultry Science Journal, 66: 751-766. 2010.

Khajali F, Khoshouie EA, Dehkordi SK and Hematian MH. Production performance and egg quality of Hy-Line W36 laying hens fed reduced-protein diets at a constant total sulfur amino acid: lysine ratio. Journal of Applied Poultry Research, 17: 390-397. 2008.

Khajali F, Liyanage R and Wideman RF. Methylglyoxal and pulmonary hypertension in broiler chickens. Poultry Science, 90: 1284-1296. 2011a.

Khajali F, Tahmasebi M, Hassanpour H, Akbari MR, Qujeq D and Wideman RF. Effects of supplementation of canola mealbased diets with arginine on performance, plasma nitric oxide, and carcass characteristics of broiler chickens grown at high altitude. Poultry Science, 90: 2284-2296. 2011 b.

Khajali F, Heydary Moghaddam M and Hassanpour H. An Larginine supplement improves broiler hypertensive response and gut function in broiler chickens reared at high altitude. International Journal of Biometeorology 58: 1175-1179. 2014.

Khajali F and Wideman RF. Nutritional approaches to ameliorate pulmonary hypertension in broiler chickens. Journal of Animal Physiology and Animal Nutrition, DOI: 10.1111/jpn.12315 (Early view). 2015

Kirby KY, McNew RW, Anthony NB, Kirby JD, Marson NE, Hughes JD and Wideman RF. Electrocardiographic evaluation of boilers following unilateral occlusion of an extrapulmonary primary bronchus. Poultry Science, 78: 242-254. 1999.

Laudadio V, Assantino P, Perillo LA, Lopresti G, Passantino A, Khan RU and Tufarelli V. Productive performance and histological features of intestinal mucosa of broiler chickens fed different dietary protein levels. Poultry Science, 91: 265-270. 2012.

Lee BJ, Lin JS, Lin YC and Lin PT. Effects of L-carnitine supplementation on oxidative stress and antioxidant enzymes activities in patients with coronary artery disease: a randomized, placebo-controlled trial. Nutrition Journal, 13: 79. 2014.

Lien TF and Horng YM. The effect of dietary L-carnitine on the growth performance, serum components, carcass traits and enzyme activities in relation to fatty acid beta oxidation of broiler chickens. British Poultry Science, 42: 92-95. 2001.

Lucas AM and Jamroz C. Atlas of Avian Hematology. Agriculture Monograph 25. US Dept. Agric., Washington, DC, 1961.

Machin M, Simoyi MF, Blemings KP and Klandorf H. Increased dietary protein elevates plasma uric acid and is associated with decreased oxidative stress in rapidly-growing broilers. Comparative Biochemistry and Physiology Part B, 137: 383-390. 2004.

Moore S and Stain WH. Chromatographic determination of amino acids by the use of automatic recording equipment. Methods in Enzymology, 6: 819-831. 1963.

Ning W and Zhao K. Propionyl-L-carnitine induces eNOS activation and nitric oxide synthesis in endothelial cells via PI3 and Akt kinases. Vascular Pharmacology, 59: 76-82. 2013. 
NRC. National Research Council. Nutrient Requirements of Poultry. 9th rev. ed. National Academy Press, Washington. 1994.

Olkowski AA, Nain S, Wojnarowicz C, Laarveld B, Alcorn J and Ling BB. Comparative study of myocardial high energy phosphate substrate content in slow and fast growing chicken and in chickens with heart failure and ascites. Comparative Biochemistry and Physiology Part A: Molecular and Integrative Physiology, 148: 230-238. 2007.

Rabie MH and Szilagyi M. Effects of L-carnitine supplementation of diets differing in energy levels on performance, abdominal fat content, and yield and composition of edible meat of broilers. British Journal of Nutrition, 80: 391-400. 1998.

Rodehutscord M, Timmler R and Dieckmann A. Effect of Lcarnitine supplementation on utilisation of energy and protein in broiler chicken fed different dietary fat levels. Archives of Animal Nutrition, 56: 431-441. 2002.

Rosebrough RW, Mcmurty JP and Vasilatos-Younken R. Dietary fat and protein interactions in the broiler. Poultry Science, 78: 992-998. 1999.

Saedi, M and Khajali F. Blood gas values and pulmonary hypertension as affected by dietary sodium source in broiler chickens reared at cool temperature in a high-altitude area. Acta Veterinaria Hungrica, 58: 379-388. 2010.

Saffar A and Khajali F. Application of meal feeding and skip-a-day feeding with or without probiotics for broiler chickens grown at high-altitude to prevent ascites mortality. American Journal of Animal and Veterinary Sciences, 5: 13-19. 2010.

Sharifi AM, Zare B, Keshavarz M and Ghaderpanahi M. Effect of short term treatment of L-carnitine on tissue ACE activity in streptozotocin-induced diabetic rats. Pathophysiology, 16: 5356. 2009.

Stenens L. Lipids and their metabolism. In: Avian Biochemistry and Molecular Biology. pp. 46-56. Cambridge University Press. Cambridge. 1996.

Tan X, Hu SH and Wang XL. The effect of dietary L-carnitine supplementation on pulmonary hypertension syndrome mortality in broilers exposed to low temperatures. Journal of Animal Physiology and Animal Nutrition, 92: 203-210. 2008.

Walton JP, Julian RJ and Squires EJ. The effects of dietary flax oil and antioxidants on ascites and pulmonary hypertension in broiler chickens using a low temperature model. British Poultry Science, 42: 123-129. 2001.

Wideman RF, Hamal KR, Bayota MT, Lorenzoni AG, Cross D, Khajali F, Rhoads DD, Erf GF and Anthony NB. Plexiform lesions in the lungs of domestic fowl selected for susceptibility to pulmonary arterial hypertension: incidence and histology. Anatomical Record, 294: 739-755. 2011.

$\mathrm{Xu}$ ZR, Wang MQ, Mao HX, Zhan XA, Hu CH. Effects of $\mathrm{L}$-carnitine on growth performance, carcass composition, and metabolism of lipids in male broilers. Poultry Science, 82: 408-413. 2003.

Yousefi A, Khajali F, Hassanpour H and Khajali Z. Dietary Lcarnitine improves pulmonary hypertensive response in broiler chickens subjected to hypobaric hypoxia. Journal of Poultry Science, 50: 143-149. 2013. 